\title{
Energy Management Strategy Using ANFIS Approach for Hybrid Power System
}

\author{
Karthik SURULI, Vennila ILA
}

\begin{abstract}
Renewable Energy Sources are the promising hopes of upcoming years as they are abundant in nature and available free of cost. In addition to this, these sources are pollution-free which makes them a perfect substitute for fossil fuels. A Hybrid Power System (HPS) is one that has multiple power generating sources like Photo Voltaic (PV) system, Wind turbine, Fuel cell, etc. interconnected to supply electric power for varying demand requirements with / without energy storage backup. This paper concentrates on the automation for control and integration of Renewable energy systems Viz. PV system, Solid Oxide Fuel Cell (SOFC) with Nickel-Metal-Hydride (Ni-MH) battery together with a variable load. The Proposed HPS mainly focuses on the use of PV which is $100 \%$ clean in nature with no toxic emissions on power generation. Here, the solar photovoltaic system with power extracting maximum by algorithm used as the major supply contributor in the HPS to meet with variable load demands. If there is a deficit of power supply from PV, the power from the Ni-MH battery / SOFC is utilized to meet the varying load demands. On the other hand, if there is excess supply from PV system, the excess energy will be stored in the Ni-MH battery. For efficient supply-demand balance, the HPS makes use of various control strategies namely Proportional Integral (PI) and Adaptive Neuro Fuzzy Inference System (ANFIS).
\end{abstract}

Keywords: Adaptive Neuro Fuzzy Inference System (ANFIS); Maximum Power Point Tracking system (MPPT); Nickel-Metal-Hydride (Ni-MH); Photo Voltaic (PV); Solid Oxide Fuel Cells (SOFC)

\section{INTRODUCTION}

The modeling of hybrid Power Systems (HPS) is looked upon for maximum power utilization and efficient renewable resources integration with overall controlling the system. A non-linear frequency droop scheme [1] is implemented for PV and Fuel cell-based Micro grids focusing on reliability and the cost aspects. The energy management scheme [2] for a micro grid with a diesel generator and renewable generators such as $\mathrm{PV}$ and fuel cell is discussed. In [3] grid connected multi-source system and optimal cost analysis are discussed using COTS (Commercial off the Shelf) components. It proposes essential domestic appliance utilized by the PV system.

A Neuro-fuzzy controller [4] with a minimum of 5 rules is used to control the output of PV which is less effective. The inverter with current fed is designed for PV / FC system [5]. The energy management approach for the Polymer electrolyte membrane fuel cell and Photo Voltaic array is concerned with the comparative analysis of a PD and Fuzzy controller with 8 rules making the controller action least effective [6].The Sliding Mode of Fuzzy Logic Controller [7] with a Multi objective particle swarm optimization algorithm is used for hybrid FC-PV-WindBattery systems which compares the PI with basic Fuzzy controller. The Pollution issues arising out of the usage of Fossil fuels are discussed for an electric ship [8] which makes use of an Integrated Power System based on Fuel cell, Battery, PV panels and two diesel generators. The energy management approach for the Photo Voltaic array \& Proton-Exchange Membrane Fuel Cells with the Li-ion battery using a Proportional-Integral controller is discussed [9]. The three-port DC/DC converter [10] is presented for hybrid PV, FC and battery applications with interleaved boost, dual operated buck- boost and SEPIC converters.

The energy and the wireless network performance access network [11] are analyzed for the conventional electricity grid with a PV system. But the MPPT is not analyzed .The adaptive strategy [12] of power management control for the PV array and FC stack escorted with hybrid storage devices with super capacitors and electrolyzer is discussed. A Power Management Scheme with PI
Controller for a hybrid AC / DC micro grid is discussed with 3 operational modes only [13]. A wind generator / PV / FC micro grid for non-linear and unbalanced loads is discussed [14]. The hybrid AC / DC system with interregional wind power which enhances the system operation under the receiving-side pressure [15]. Similarly, [16-20] explains the various control features used for energy management system in hybrid power network. The power electronic converter is playing a vital role in effective control of the EMS [21-25]. The grid connection issues like frequency deviation, voltage drop and control related issues are explained in [26-29]. The Adaptive control techniques and their importance in renewable network are explained in [30-33].

The fuel cell taken into consideration in all these papers was mostly PEMFC which had $40-50 \%$ efficiency compared with SOFC used in the proposed HPS having better efficiency rate of $60 \%$. The proposed study uses a robust, efficient model comprised of PV System, SOFC, and Ni-MH battery together with variable built in loads having tools tag in Simulink platform. The proposed system highlights the modeling parameter in the HPS by using more sophisticated ANFIS controller. The controller performance is analyzed and compared with the PI controller and its performance is found to be better.

\section{MODELLING OF HPS}

The proposed structure is a standalone system composed of PV System, SOFC, and a Ni-MH battery together with a variable load. The proposed HPS is shown below in Fig. 1. All the components that constitute the HPS Viz. the PV System, SOFC, Ni-MH battery share the same DC bus.

The HPS uses an efficient EMS incorporated with the PI \& ANFIS controller to meet with dynamic load variations. EMS gives control to the battery converter for delivering maximum power $\left(P_{B A T}\right)$ and appeals the reference $P_{\mathrm{BAT}}=P_{\mathrm{LOAD}}-P_{\mathrm{PV}}+P_{\mathrm{SOFC}}$. Hence the surfeit demand power is provided by the Ni-MH battery. If $P_{\mathrm{BAT}}$ $<P_{\mathrm{LOAD}}$, then $P_{\mathrm{PV}}+P_{\mathrm{SOFC}}$ acts as a vital player in this operating mode. The outstanding reference power demand 
is established to the boost converter by EMS which is given by $P_{\mathrm{PV}}+P_{\mathrm{FC}}=P_{\mathrm{LOAD}}-P_{\mathrm{BATT}}$. Hence the total demand in power is provided by $\mathrm{PV}$ System, SOFC and Ni-MH battery systems.

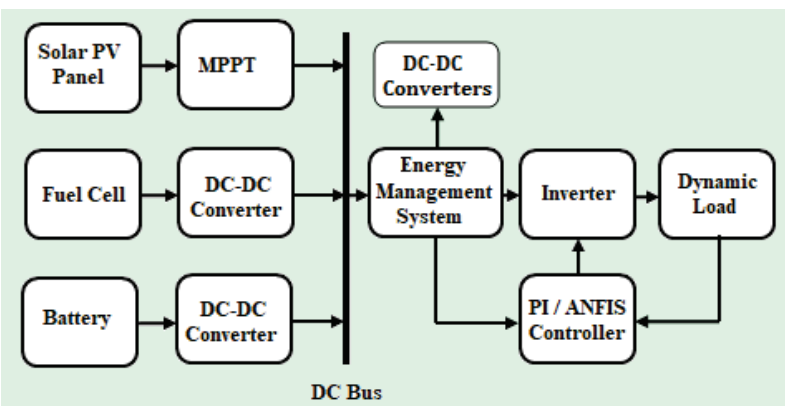

Figure 1 Hybrid power system-block diagram

\subsection{Modelling of PV}

A photovoltaic (PV) system composed of one or more solar PV panels combined with an inverter. The equivalent circuit model of the PV cell is shown below in Fig. 2. It is the combination of $\mathrm{PN}$ junction diode $\mathrm{D}$ with shunt connected current source $I_{\mathrm{ph}}$ which varies with solar radiation, shunt connected resistance $R_{\mathrm{sh}}$ and series connected resistance $R_{\mathrm{s}}$

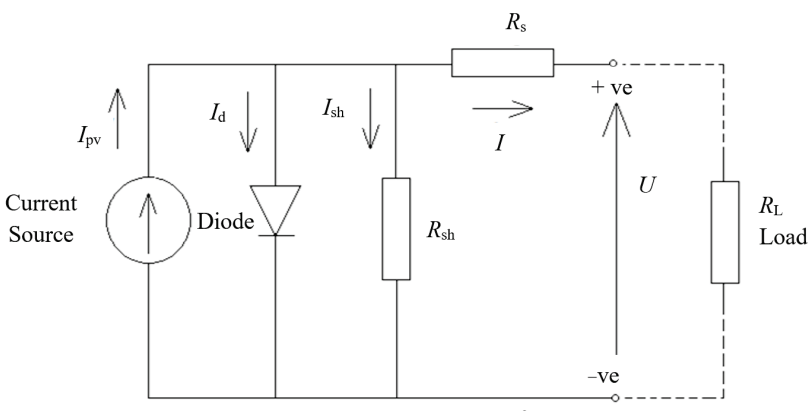

Figure 2 Equivalent circuit model of the PV cell

Applying KCL to Fig. 2, the output current of the PV system is given as:

$I=I_{\mathrm{PV}}-I_{\mathrm{d}}-I_{\mathrm{sh}}$

The photo current i.e., terminal current form photocell depends on solar irradiance and temperature is given by the causal equations:

$I=I_{\mathrm{PV}}-I_{\mathrm{s}}\left[\exp \left(\frac{V+I R_{\mathrm{S}}}{a V_{\mathrm{t}}}\right)-1\right]-\frac{V+I R_{\mathrm{S}}}{R_{\mathrm{sh}}}-I_{\mathrm{sh}}$

$I_{\mathrm{s}}=\frac{I_{\mathrm{sc}}}{\exp \left(\frac{V_{\mathrm{oc}}}{a V_{\mathrm{t}}}\right)-1}$

$I_{\mathrm{d}}=I_{\mathrm{s}}\left[\exp \left(\frac{V+I R_{\mathrm{s}}}{a V_{\mathrm{t}}}\right)-1\right]$

$I_{\mathrm{sh}}=\frac{\left(V+I R_{\mathrm{s}}\right)}{R_{\mathrm{sh}}}$

$V_{\mathrm{t}}=\frac{K T N_{\mathrm{s}}}{q}$
Where $N_{\mathrm{s}}$ is series-connected solar cells, $I_{\mathrm{PV}}$ is photo current, $I_{\mathrm{S}}$ denotes reverse saturation current which depends on material, doping and temperature levels, $R_{\mathrm{s}}$ and $R_{\mathrm{sh}}$ represent the series and parallel inherent resistances of the cell, $q$ is the electron charge $1,60217646 \times 10^{-19} \mathrm{C}, k$ is Boltzmann's constant $1,3806503 \times 10^{-23} \mathrm{~J} / \mathrm{K}$ and $a$ represents the modified diode ideality factor. The modeling parameter of the PV System is illustrated in Tab. 1.

Table 1 PV system parameters
\begin{tabular}{|l|c|}
\hline \multicolumn{2}{|c|}{ Parameters } \\
\hline Maximum Power & Values \\
\hline Open Circuit Voltage $V_{\mathrm{oc}}$ & $400 \mathrm{~W}$ \\
\hline Short Circuit Current $I_{\mathrm{sc}}$ & $49,4 \mathrm{~V}$ \\
\hline Maximum Voltage at maximum power $V_{\mathrm{mpp}}$ & $10,49 \mathrm{~A}$ \\
\hline Maximum Current at maximum power $I_{\mathrm{mpp}}$ & $40,8 \mathrm{~V}$ \\
\hline Shunt Resistance $R_{\mathrm{sh}}$ & $9,81 \mathrm{~A}$ \\
\hline Series Resistance $R_{\mathrm{s}}$ & $550 \Omega$ \\
\hline
\end{tabular}

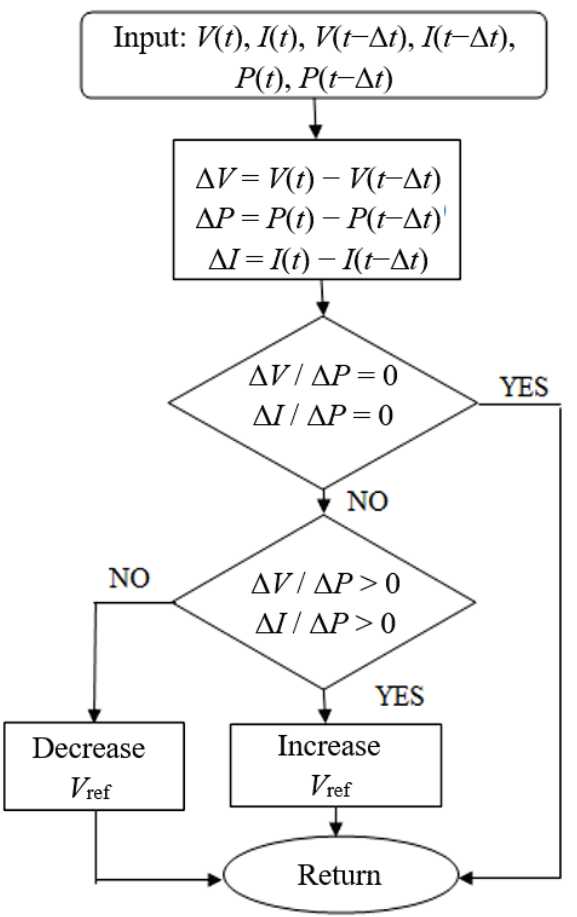

Figure 3 Incremental conductance algorithm

\subsection{Maximum Power Point Tracking Systems (MPPT)}

The photovoltaic system proposed in the HPS is incorporated with the MPPT technique. The energy efficiency of the MPPT control algorithm is given by:

$\eta_{\mathrm{MPPT}}=\frac{\int_{0}^{T} P_{\mathrm{PV}-\max }(t) \mathrm{d} t}{\int_{0}^{T} P_{\mathrm{V}-\mathrm{MPPT}}(t) \mathrm{d} t}$

where $P_{\mathrm{V}-\mathrm{MPPT}}$ represents the power output of PV with MPPT, $P_{\mathrm{PV}-\max }$ is the actual power output at the maximum power point condition. The mode of operation is explained in the incremental conductance algorithm flowchart in Fig. 3. This algorithm eliminates the cons of the Perturb \& Observe method by tracking Maximum Power Point for varying metrological conditions. The PV System voltage and current are measured at fixed sampling intervals and 
are fed to the controller to calculate the power of the PV System. The instant conductance of the PV System is measured by dividing the PV System current with the voltage. These variables are updated and stored, the system tracks the MPPT by comparing with the incremental and instantaneous conductance of the PV System until the MPPT is reached when $\mathrm{d} P_{\mathrm{PV}} / \mathrm{d} V_{\mathrm{PV}}=0$.

\subsection{Solid Oxide Fuel Cells (SOFC)}

A fuel cell is an electro-chemical device that produces electricity without combustion by combining the hydrogen and oxygen to produce water and heat. SOFC Works at higher temperatures. They use a solid ceramic electrolyte, such as zirconium oxide stabilized with yttrium oxide, instead of a liquid and operate at $800{ }^{\circ} \mathrm{C}$ to $1000{ }^{\circ} \mathrm{C}$. The equivalent circuit of a SOFCNi-MH fuel cell is shown below in Fig. 4.

The fuel cell used in the proposed HPS is Solid oxide fuel cell which assumes the following:

a) The fuel cell gases are ideal.

b) Only one pressure is defined in the interior of the electrodes.

c) The fuel cell temperature is invariant.

d) Nernst's equation applies.

The equation gives the basic operation of the fuel cell as:

$$
\begin{aligned}
& 2 \mathrm{H}_{2} \leftrightarrow 4 \mathrm{H}^{+}+4 \mathrm{e}^{-} \\
& \mathrm{O}_{2}+4 \mathrm{H}^{+}+4 \mathrm{e}^{-} \leftrightarrow 2 \mathrm{H}_{2} \mathrm{O} \\
& 2 \mathrm{H}_{2}+\mathrm{O}_{2} \leftrightarrow 2 \mathrm{H}_{2} \mathrm{O}+\text { Electricity + Heat }
\end{aligned}
$$

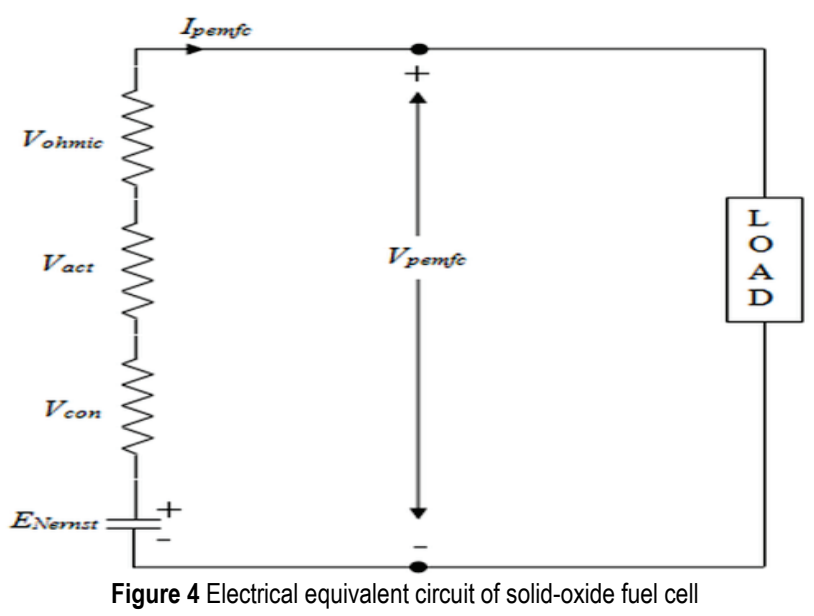

The voltage produced by a single solid-oxide fuel cell is expressed as:

$$
V_{\mathrm{SOFC}}=E_{\mathrm{Nernst}}-V_{\text {act }}-V_{\text {ohmic }}-V_{\text {con }}
$$

where $E_{\text {Nernst }}$ represents the reversible voltage which is the thermo-dynamic voltage of the cell, $V_{\text {act }}$ is the drop in voltage associated with the activation of anode and cathode, $V_{\text {ohmic }}$ is the drop in voltage resulting from the resistance of the conduction of proton through the solid membranes and the electron through its path, $V_{\text {con }}$ is the drop in voltage associated in the reactants concentration of reactants gases or mass transportation.

\subsection{Battery Energy Storage System (BESS)}

The battery is charged when the source generates power. The stored energy can be utilized later or discharged when the primary energy source is unavailable. The fuel cell-based hybrid energy systems, Ni-MH batteries are the best option since they have high energy density efficiency, lightweight and good life cycle and its equivalent circuit is as shown in Fig. 5. The battery $S o C$ level gives the energy reserve status given by percentage as:

$S o C=100\left[1-\int \frac{i_{b}}{Q} \mathrm{~d} t\right]$

where, $i_{\mathrm{b}}$ is the current in battery and $Q$ is the capacity of the battery.

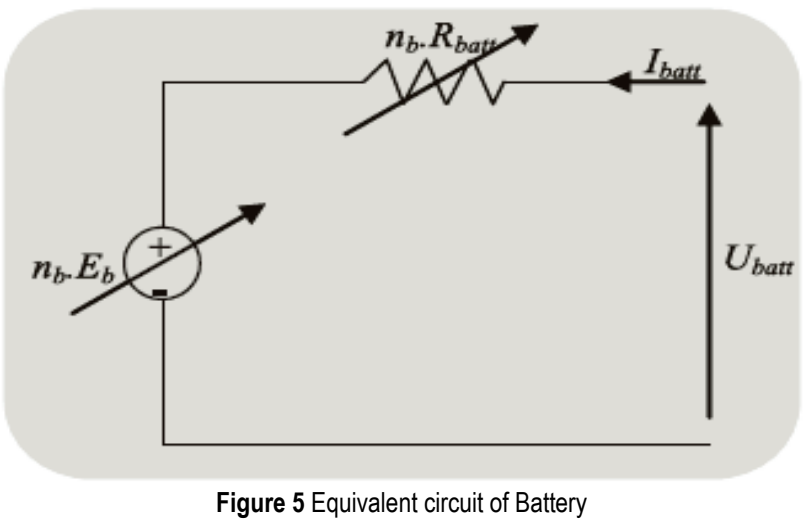

\subsection{Improved High Power DC-DC Converter}

The power handling capacity of the conventional DCto-DC boost converter is improved using passive components in the circuits as shown in Fig. 6. The proposed high power boost converter is deliberate to function in uninterrupted conduction mode.

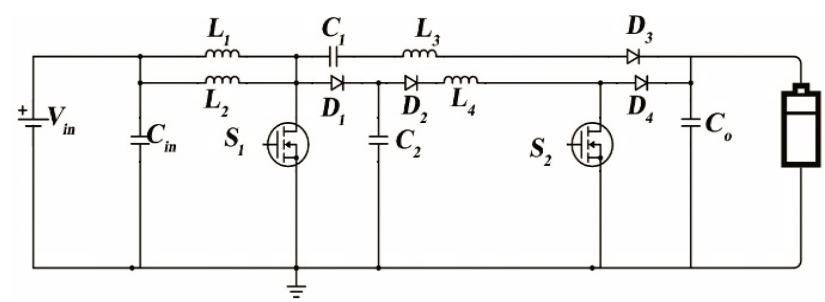

Figure 6 Equivalent circuit of high power DC-DC converter

The detailed explanations of operational mode of the proposed DC to DC boost converter are described as follows:

Mode1: In this mode of operation, the switches $S_{1}$ and $S_{2}$ are turned-ON. The inductors, $L_{1}$ and $L_{2}$ are energized by the input voltage source $\left(V_{\text {in }}\right)$ which causes the magnetizing current, $I_{L 1}$, and $I_{L 2}$ to increase gradually. When $S_{1}$ switch is ON, conventional boost operation occurs through the inductor $L_{1}$ and capacitor $C_{1}-L_{3}-D_{3}$ and $C_{\mathrm{o}}$. When $\mathrm{S}_{2}$ switch is ON, a loop $C_{2}-D_{2}-L_{4}-S_{2}$. 
Thus, the capacitor, $C_{2}$ discharges its energy through inductor $L_{4}$. The passive snubber circuit which consists of $D_{1}$ and capacitor $C_{2}$ is used to protect the switch $S_{1}$ from switching transient. Similarly, the passive snubber circuit using $D_{4}$ and $C_{\mathrm{o}}$ will protect the switch $S_{2}$ from switching transient.

Mode 2: When the switches $S_{1}$ and $S_{2}$ are turned off under zero voltage switching. In this mode, the secondary current, $I_{L 3}$, and $I_{L 4}$ decreases gradually and reaches zero. When the switch voltage of the clamped diode, $D_{1}, D_{2}$ and $D_{3}$ transfers energy of the primary inductor, $L_{1}$ and $L_{2}$ toward the capacitor $C_{0}$. Here, the clamped diodes, $D_{1}, D_{2}$, and $D_{3}$ have considered ultra-fast clamping diodes with low power consumption.

\section{ENERGY MANAGEMENT STRATEGIES}

The Energy Management Strategy used in the proposed HPS makes use of measurement of power produced from the sources and power consumed by the load. The flowchart of the proposed HPS is given in Fig. 7. The power produced from PV $\left(P_{\mathrm{PV}}\right)$, Fuel Cell $\left(P_{\text {fuel }}\right)$ and the power requirement from load cell $\left(P_{\text {load }}\right)$ is measured together with the $S o C$ of the battery. The HPS computes the sum of total power production $\left(P_{\text {hyd }}\right)$ as the sum of power produced from $\mathrm{PV}$ and fuel cells $\left(P_{\mathrm{PV}}+P_{\text {fuel }}\right)$. The HPS analyses the working of the system under three cases and it operates in 5 modes.

Case 1: When the produced total power matches the load requirement $\left(P_{\text {hyd }}=P_{\text {load }}\right)$

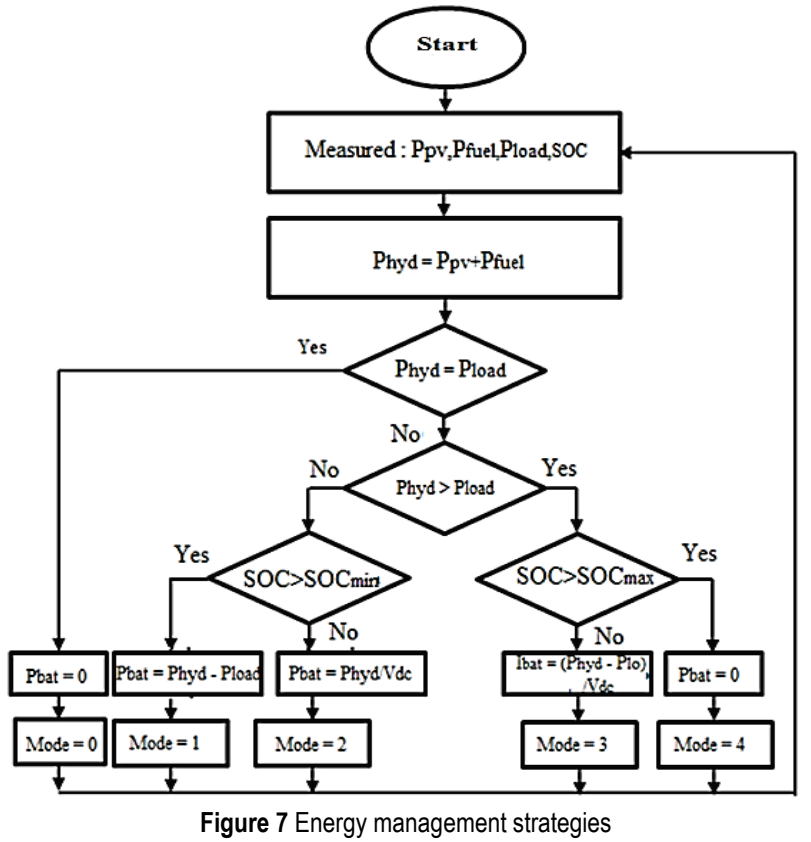

This case applies when power demanded from load matches that of power produced from PV and fuel cell. Under this condition, the load requirement is met with ease and no Power is taken from the battery $\left(P_{\text {bat }}=0\right)$. This operational mode is referred to as mode 0 .

Case 2: When the produced total power is less than the requirement of load $\left(P_{\text {hyd }}<P_{\text {load }}\right)$. This case applies when power demanded from the load is higher than the power produced from PV and fuel cell. In this the excess load demand is met from the power in the battery if $\mathrm{SoC}>$
$S o C_{\min }$ and power drawn from the battery is the difference between hybrid power and load power. This operational mode is referred to as mode 1 . If in case the load demand is high and if $S o C<S o C_{\min }$, the battery will be getting charged $\left(I_{\text {bat }}\right)$ from the hybrid power supply as the load keeps on dynamically varying and it falls off. This operational mode is referred to as mode 2.

Case 3: When the produced total power is greater than the requirement of load ( $\left.P_{\text {hyd }}>P_{\text {load }}\right)$.

This case applies when the power produced from the source exceeds that of load demands. The EMS analyzes the $S o C$ of the battery. If the power produced from the sources is in excess quantity and if $S o C<S o C_{\max }$, then the excess power starts getting stored in the battery to meet up with future requirements. This operational mode is referred to as mode 3. If $\mathrm{SoC}>S o C_{\max }$, then charging of the battery does not happen $\left(P_{\text {bat }}=0\right)$. This operational mode is referred to as mode 4.

\section{PROSES OF FUEL CELL ADDITION TO HPS}

Solid oxide fuel cells give demanding issues in controlling the load due to its nonlinearity and strict operating and sluggish dynamics which plays a vital role in reducing Battery current overshoot and undershoots.
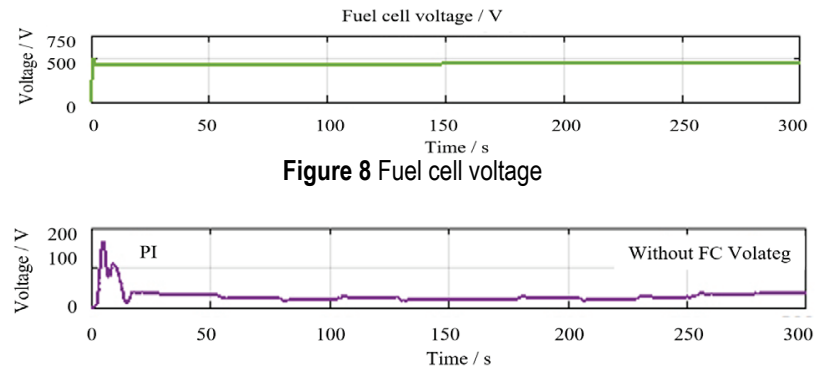

(a)

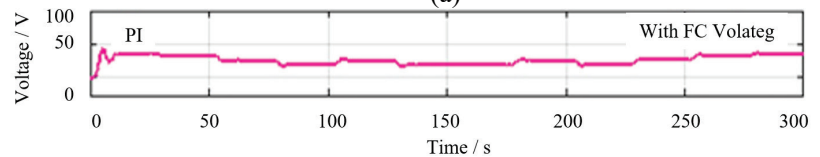

(b)

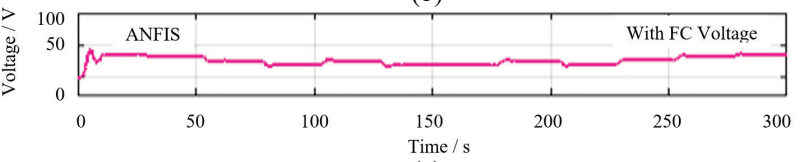

(c)

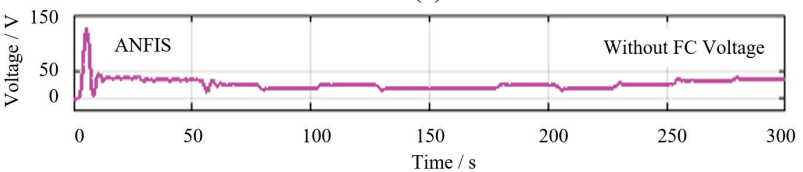

(d)

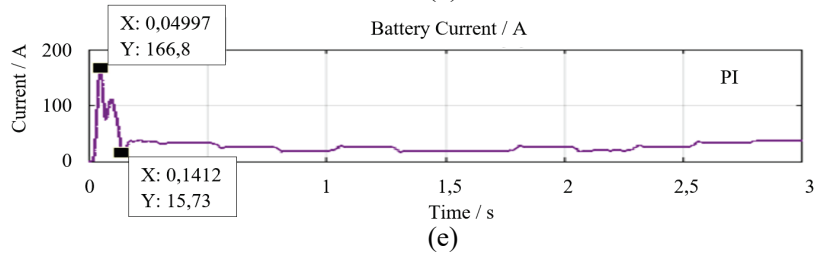

Figure 8 Load power: a) without SOFC voltage using PI controller,

b) with SOFC voltage using PI controller, c) without SOFC voltage using ANFIS controller, d) with SOFC voltage using ANFIS controller, e) without SOFC voltage showing overshoot \& undershoot values

After a short transient period if the load varies, the ANFIS controller immediately brings the system to the stable condition compared to the PI controller as shown in 
Fig. 8(a) to Fig. 8(d) which refers to the load power met with PI \& ANFIS controller and Tab. 2 lists out the transient response values of SOFC.

\begin{tabular}{|c|c|c|c|c|}
\hline \multirow[b]{2}{*}{ Controller } & \multicolumn{4}{|c|}{ Battery Load Current (A) } \\
\hline & $\begin{array}{c}\text { Without } \\
\text { SOFC voltage }\end{array}$ & $\begin{array}{c}\text { With SOFC } \\
\text { voltage }\end{array}$ & $\begin{array}{l}\text { Overshoot } \\
/ \mathrm{s}\end{array}$ & $\begin{array}{l}\text { Undershoot } \\
/ \mathrm{s}\end{array}$ \\
\hline PI & 166,80 & 43,53 & 0,05 & 0,55 \\
\hline ANFIS & 124,20 & 38,76 & 0,04 & 0,14 \\
\hline
\end{tabular}

It is evident from Fig. 8(e) that PI controller has higher overshoot and undershoot values, which are eliminated by adding fuel cells in parallel. Fig .9(a) to Fig. 9(c) give the battery power in presence of SOFC for both PI and ANFIS controllers. It is observed from Fig. 9(b) and Fig. 9(d) that in the absence of SOFC both PI \& ANFIS controllers draw a battery current of higher magnitude.

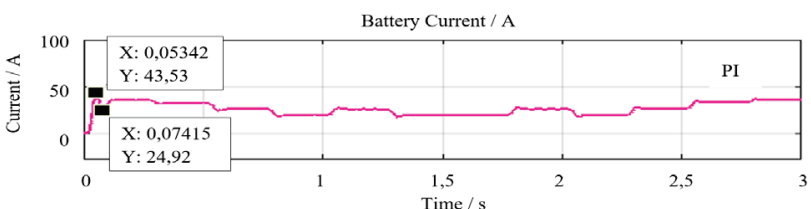

(a)

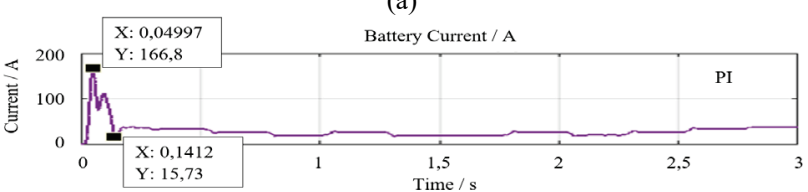

(b)

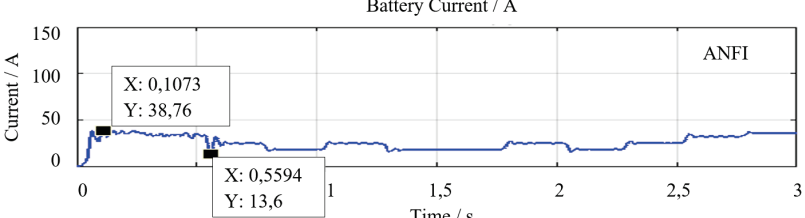

(c)

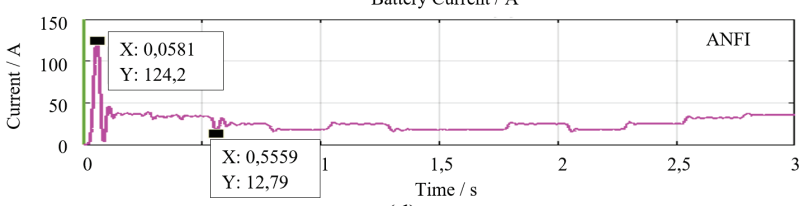

(d)

Figure 9 Battery current drawn in the a) presence of SOFC (PI), b) absence of SOFC (PI), c) presence of SOFC (ANFIS), d) absence of SOFC (ANFIS)

\section{RESULTS AND DISCUSSIONS}

In HPS, a PV of $450 \mathrm{~W}$, Fuel Cell of $100 \mathrm{~kW}$ along with backup sources 6,5 Ah batteries are modeled for the utilization in the nonlinear system load. The analysis of solar irradiance and ambient temperature is shown in Fig. 10. The irradiance level varies over the 12 hours $(300$ seconds) sequence depending upon the irradiation of the sunlight.

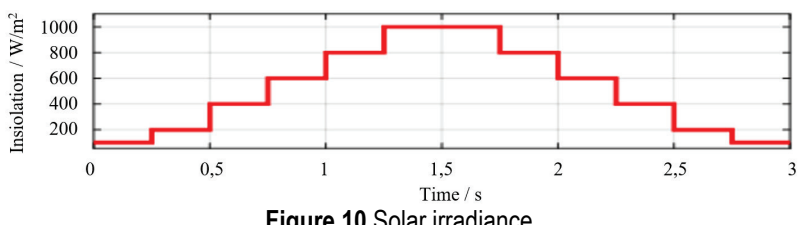

The power profile of the HPS with PI and ANFIS control is shown in Fig. 11 and Fig. 12. As seen from the graph it is evident that initially when power from PV is less from $(0-100 \mathrm{~s})$ time interval, the power from the battery is used to keep up with the load requirements. As the PV power slowly raises, the power utilized from the battery goes down which is shown in the time interval between $(100-200 \mathrm{~s})$. when there is a step-change in load from (100 $-200 \mathrm{~s})$, the battery power goes down as power from PV is high at this instance. From (200 - $300 \mathrm{~s})$, there is a sudden drop in load and PV power together and the battery power is again utilized to meet with the load demands.

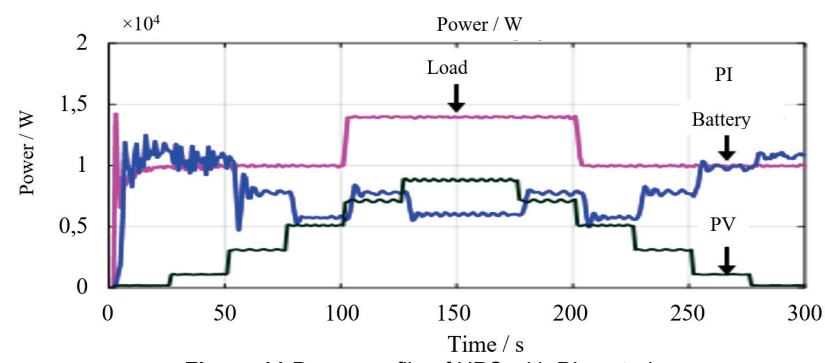

Figure 11 Power profile of HPS with PI control

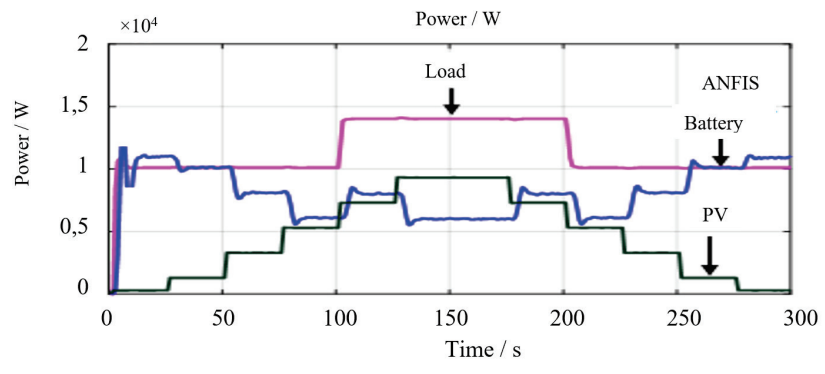

Figure 12 Power profile of HPS with ANFIS control

The PI and ANFIS load current profiles are shown in Fig. 13 and Fig. 14. This also reveals that ANFIS controllers are superior in performance to the PI controller.

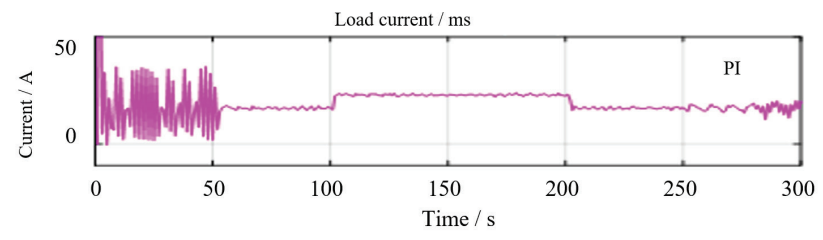

Figure 13 Load current - PI control

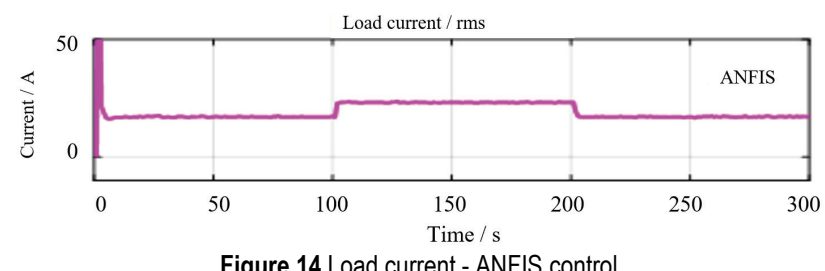

The excess generation power from PV to storage in battery system. In absence of power from renewable source the battery source backs up the energetic entire load without any deviation in dynamic variation of load. If the load requirement is met by PV and fuel cells, no power is taken from the battery. The excess power produced by the system is utilized for charging the battery in order to keep it in stable condition. Tab. 3 gives the values of power produced from PV, Fuel cell, Battery for specific insolation. It also gives a clear picture of the better performance of the ANFIS controller. The bar graph 
representation of PV, Fuel Cell and battery power for PI and ANFIS controller comparison is shown in Fig. 15 and Fig. 16.

Table 3 Simulation result of step change in irradiation

\begin{tabular}{|c|c|c|c|c|c|}
\hline \multirow{2}{*}{ TIME } & \multirow{2}{*}{ Insolation } & PV + SOFC Power / W & Battery Power / W \\
\cline { 3 - 6 } & & PI & ANFIS & PI & ANFIS \\
\hline 0 to $25 \mathrm{~s}$ & 100 & 225 & 290 & 11110 & 10950 \\
\hline 25 to $50 \mathrm{~s}$ & 200 & 1170 & 1294 & 9716 & 10150 \\
\hline 50 to $75 \mathrm{~s}$ & 400 & 3193 & 3299 & 7759 & 8140 \\
\hline 75 to $100 \mathrm{~s}$ & 600 & 5185 & 5304 & 5185 & 6112 \\
\hline 100 to $125 \mathrm{~s}$ & 800 & 7259 & 7313 & 7706 & 8034 \\
\hline 125 to $175 \mathrm{~s}$ & 1000 & 9315 & 9323 & 5704 & 6046 \\
\hline
\end{tabular}

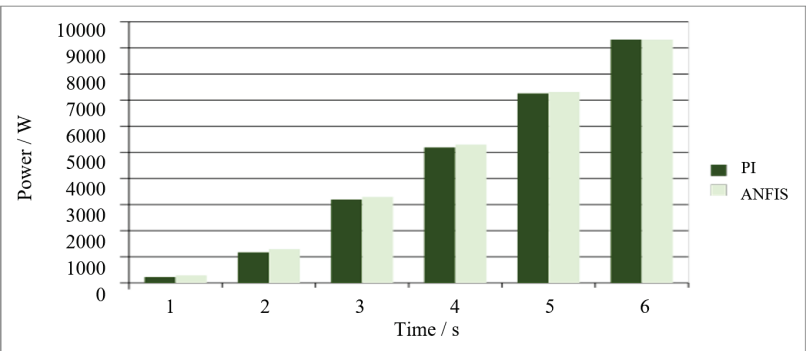

Figure 15 HPS power comparison

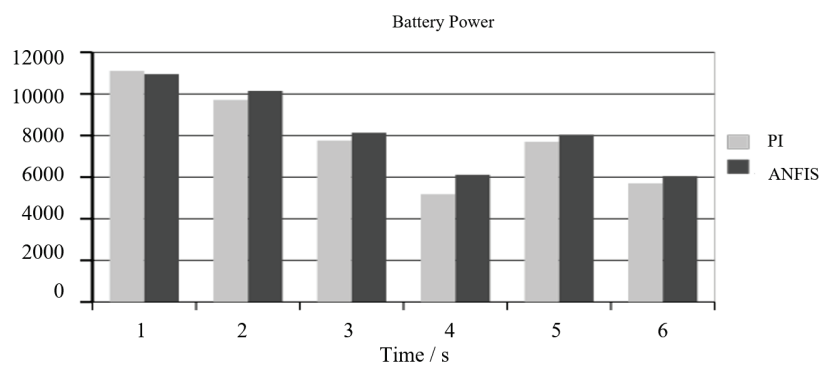

Figure 16 Battery power comparisons

The zoomed out figures of load current, load power and battery power in Fig. 17 to Fig. 22 illustrate the ANFIS controller reduces the steadystate error. It also decreases the system over-shoot, under-shoot and improves the settling time as compared to the PI controller as analyzed in Tab. 4.

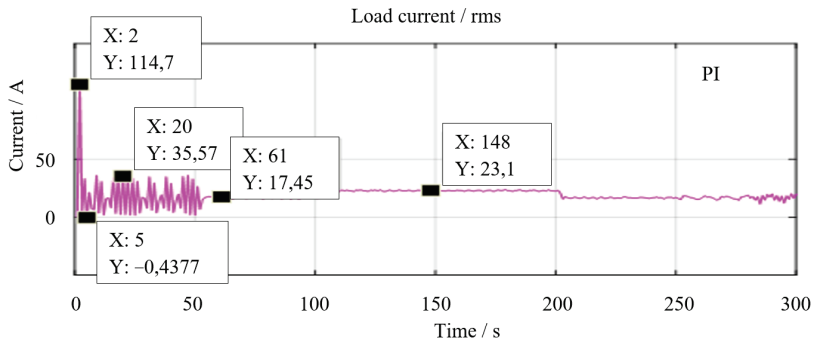

Figure 17 Load current - PI control

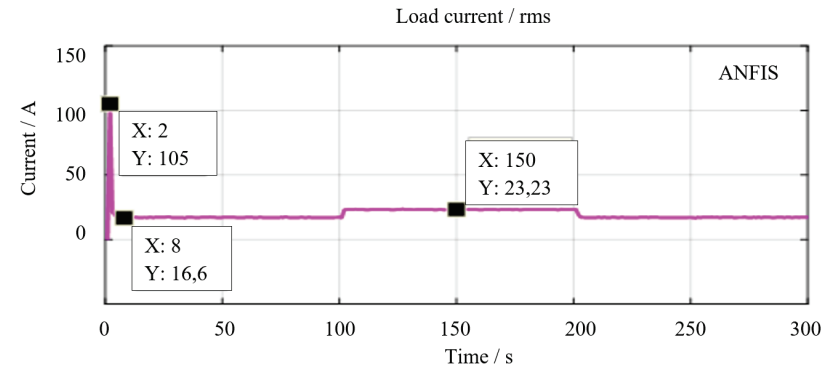

Figure 18 Load current - ANFIS control

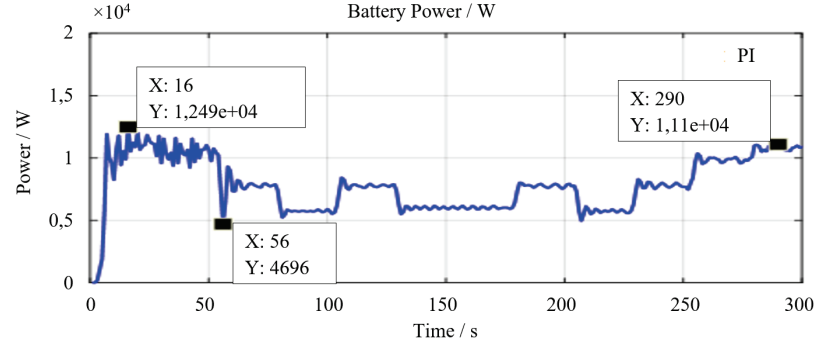

Figure 19 Battery power - PI control

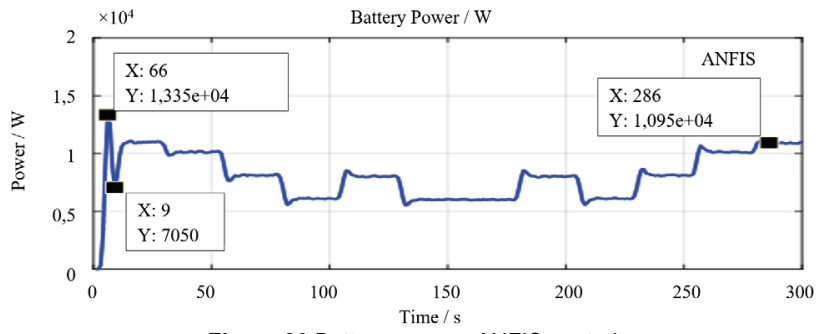

Figure 20 Battery power - ANFIS control

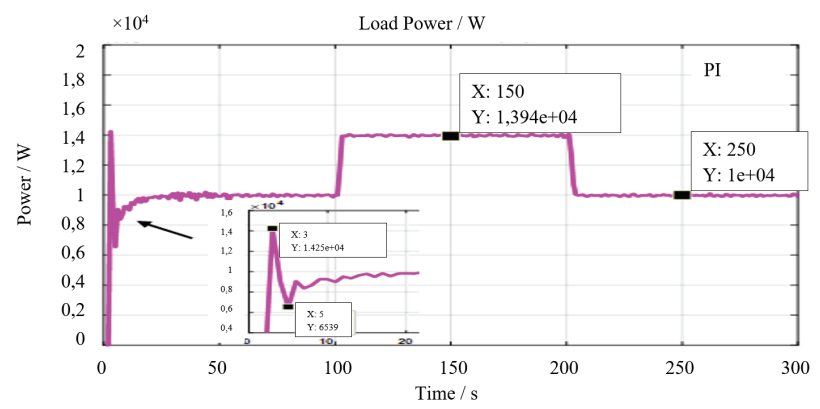

Figure 21 Load power -PI control

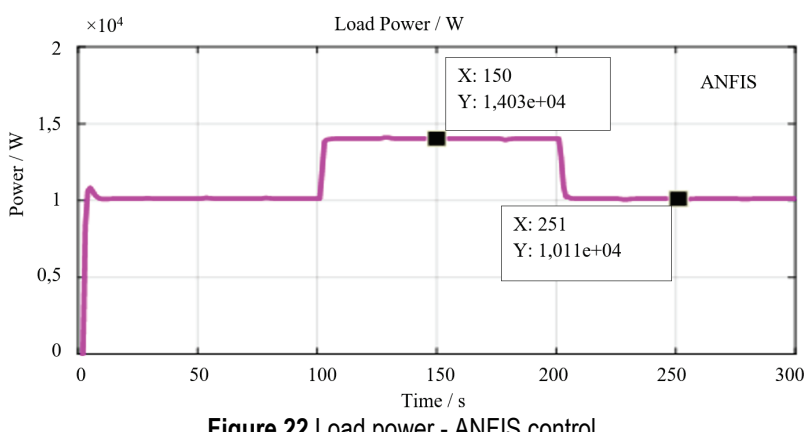

According to Tab. 4, to compare simulated result case of overshoot, undershoot and settling time with existing PI controller and proposed hybrid ANFIS controller the steady-state error is much lower in ANFIS controller than with PI control.

\begin{tabular}{|c|c|c|c|c|c|}
\hline Controller & $P_{\max }$ & $\begin{array}{c}\text { Load } \\
\text { curren } \\
t\end{array}$ & $\begin{array}{l}\text { Over- } \\
\text { shoot }\end{array}$ & $\begin{array}{l}\text { Under- } \\
\text { shoot }\end{array}$ & $\begin{array}{l}\text { Settling } \\
\text { time / s }\end{array}$ \\
\hline Current / A, with PI & - & 17,50 & 114,70 & 0,43 & 61 \\
\hline $\begin{array}{c}\text { current / A, with } \\
\text { ANFIS }\end{array}$ & - & 17,50 & 105,00 & 2,00 & 8 \\
\hline $\begin{array}{c}\text { Battery Power / W, } \\
\text { with PI }\end{array}$ & 10950 & - & 12490 & 4696 & 64 \\
\hline $\begin{array}{c}\text { Battery Power / W, } \\
\text { with ANFIS }\end{array}$ & 10950 & - & 13350 & 7050 & 20 \\
\hline Power / W, with PI & 10110 & - & 14250 & 6539 & 50 \\
\hline $\begin{array}{c}\text { Power / W, with } \\
\text { ANFIS }\end{array}$ & 10110 & - & 0 & 0 & 5 \\
\hline
\end{tabular}


The proposed HPS system analyses the load current and load voltage THD percentage. To ensure power quality, assumptions are applied according to the IEEE 1547 standard. From Fig. 23 to Fig. 30, it is observed the Voltage and current THD is $8,54 \%$ for PI controller and $5,89 \%$ and $5,90 \%$ for ANFIS respectively as tabulated in Tab. 5. It is clear from Tab. 5, that the maximum deviation of Current THD and voltage THD is less in the ANFIS controller compared to the PI controller.
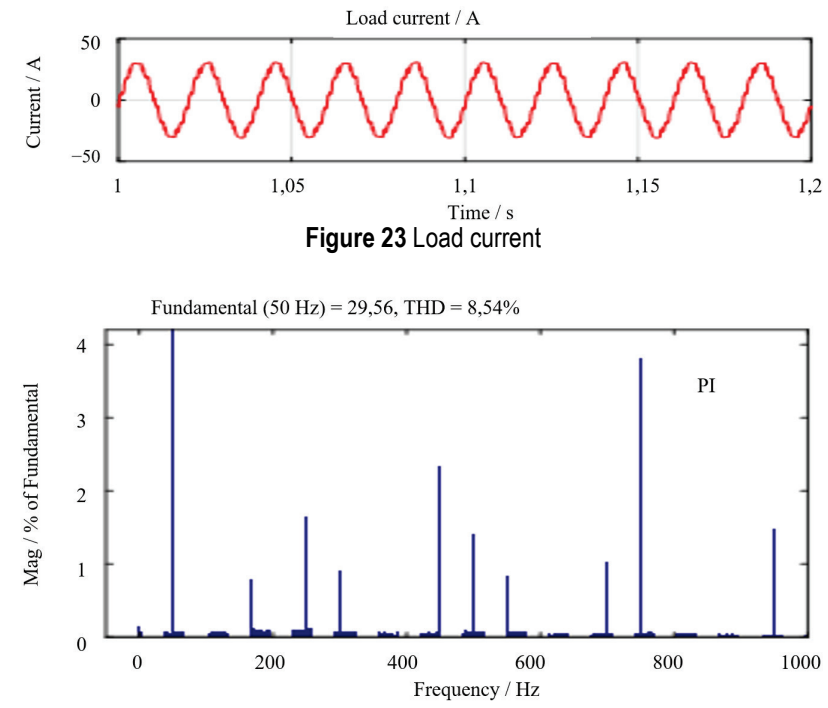

Figure 24 Load current - THD with PI control
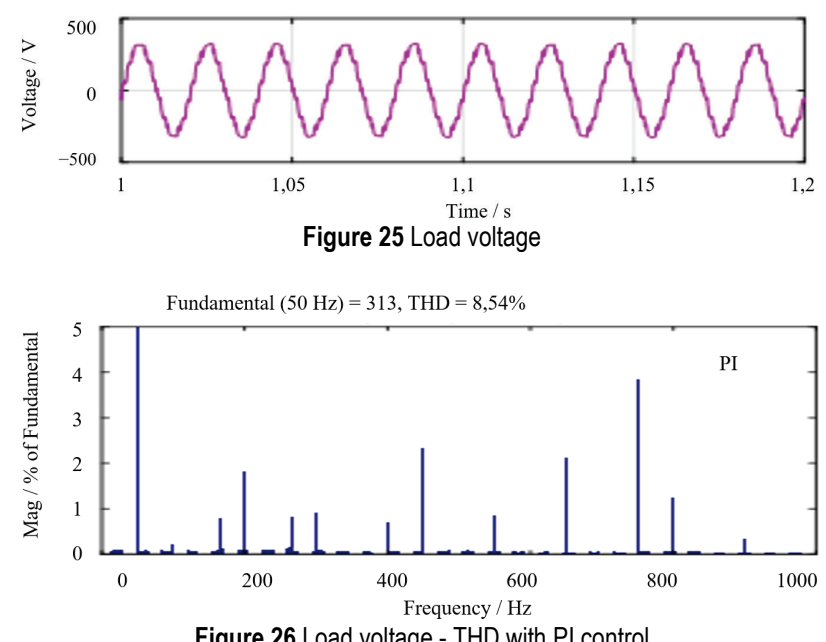

Figure 26 Load voltage - THD with PI control
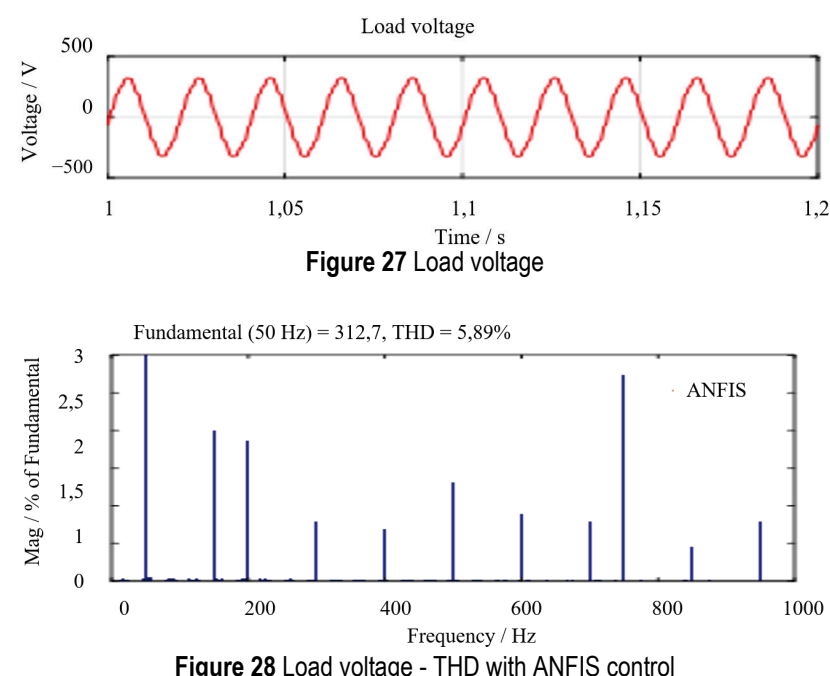

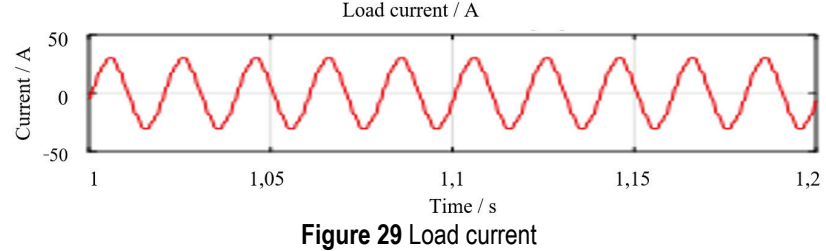

Figure 29 Load current

Table 5 THD comparisons

\begin{tabular}{|c|c|c|}
\hline Parameter & PI & ANFIS \\
\hline Voltage $V$ & 8,54 & 5,89 \\
\hline Current $I$ & 8,54 & 5,90 \\
\hline
\end{tabular}

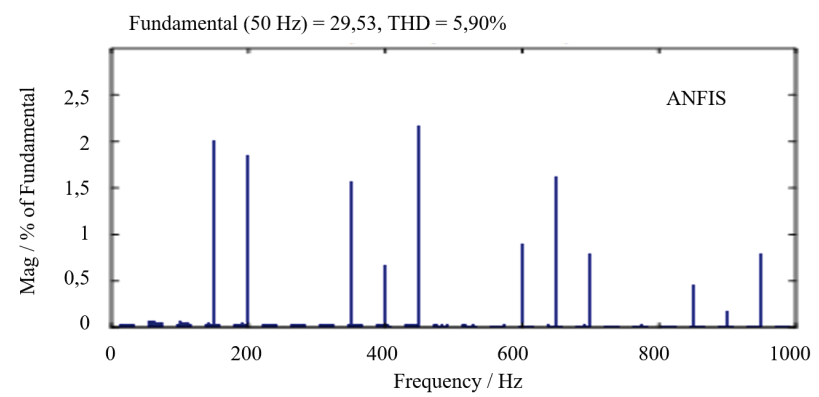

Figure 30 Load current - THD with PI control

\section{CONCLUSIONS}

A Hybrid Power System, in general, provides many advantages when used with integrated renewable energy sources in terms of various factors like High system availability, less cost, low maintenance, better load matching, and higher fuel efficiency. The proposed HPS offers the mentioned advantages together with efficient control action incorporated for faster control action to cope up with dynamic load variation in spite of unstable supply from PV. The proposed model proves better in performance with ANFIS control than PI Control. This is verified using a controller parameter comparison. The transient analysis of the HPS is done for PI and ANFIS which also reveals that ANFIS control has less THD for both current \& voltage than PI. Also, it was proved that for a given load power, ANFIS control settles in a shorter period with less overshoot and undershoot.

The usage of the ANFIS controller on these advantages increases the proposed system efficiency. Also, the usage of SOFC in the system makes it more effective in performance. This factor has been verified in the proposed HPS by examining the performance of the system both in the presence $\&$ absence of SOFC. In the presence of SOFC, the only very little amount of power was drawn from NiMH battery. SOFC being more efficient, in turn, increases the overall efficiency of the system. Thus, the proposed HPS proves more efficient in terms of load matching with the presence of a dual combination of SOFC and ANFIS Control.

\section{REFERENCES}

[1] Cingoz, F., Elrayyah, A., \& Sozer, Y. (2016). Optimized Resource Management for PV Fuel Cell Based Micro grids using Load Characterizations. IEEE Transactions on Industrial Applications, 52(2), 1723-1735. https://doi.org/10.1109/TIA.2015.2499287

[2] Sekhar, P. C. \& Mishra, S. (2016). Storage Free Smart Energy Management for Frequency Control in a Diesel PV 
Fuel Cell-Based Hybrid AC Micro grid. IEEE Transactions on Neural Networks and Learning Systems, 1-15. https://doi.org10.1109/TNNLS.2015.2428611

[3] Sidra, M. \& Laiq, K. (2017). Adaptive control paradigm for photovoltaic and solid oxide fuel cell in a grid integrated hybrid renewable energy system, PLOS ONE. https://doi.org/10.1371/journal.pone.0173966

[4] Maxx, P., Narciso, F. M., Arunachala, M., \& Kannan, M. (2014). Hybrid Microgrid Model Based on Solar Photovoltaic Battery Fuel Cell System for Intermittent Load Applications. IEEE Transactions on Energy Conversion, 30(1), 1-8. https://doi.org/10.1109/TEC.2014.2352554

[5] Xiaofeng, S., Bingjie, L., Yao, C., Haoxiang, Z., Yanping, Z., \& Baocheng, Wang. (2016). Frequency based power management for photovoltaic battery fuel cell electrolysis standalone micro grid. IET Power Electronics, 9(13), 1-9. https://doi.org/10.1049/iet-pel.2015.0663

[6] Radha, S. K., Akshay, K. R., Elena, B., \& Fei, Gao. (2015). Soft-switching Non-isolated Current-fed Inverter for PV Fuel cell Application. IEEE Transactions on Industry Applications, 52(1), 1-8. https://doi.org10.1109/TIA.2015.2472360

[7] Adel, A. A., Elgammal, M. F., \& Elnaggar. (2016). MOPSObased optimal control of shunt active power filter using a variable structure fuzzy logic sliding mode controller for hybrid (FCPV-Wind-Battery) energy utilization scheme. IET Renewable Power Generation Active Power Control of Renewable Energy Generation Systems, 11(8), 1148-1156. https://doi.org/10.1049/iet-rpg.2016.0440

[8] Mohamad, R. B. \& Rana, A. (2016). Simulation Based Modeling and Power Management of All-Electric Ships Based on Renewable Energy Generation Using Model Predictive Control Strategy. IEEE Intelligent transportation systems magazine, 8(2), 90-103. https://doi.org10.1109/MITS.2016.2533960

[9] Phatiphat, T., Suwat, S., Pongsiri, M., Luigi, P., Babak, N. M., Serge, P., \& Bernard, D. (2015). DC Bus Stabilization of Li Ion Battery Based Energy Storage for a Hydrogen Solar Power Plant for Autonomous Network Applications. IEEE Transactions on Industry Applications, 51(4), 1-9. https://doi.org10.1109//AS.2014.6978368

[10] Faezeh, K., Rana, A., \& Mohamad, R. B. (2017), A new Three Input DC/DC Converter for Hybrid PV FC Battery Applications. IEEE Journal of Emerging and Selected Topics in Power Electronics, 5(4), 1-8. https://doi.org10.1109/JESTPE.2017.2731816

[11] Margot, D., Daniela, R., Michela, M., Luc, M., \& Wout, J. (2018). Accounting for the Varying Supply of Solar Energy When Designing Wireless Access Networks. IEEE Transactions on Green Communications and Networking, 2(1), 275-290. https://doi.org 10.1109/TGCN.2017.2764164

[12] Bonu, R. N., Gayadhar, P., \& Pierluigi, S. (2017). A Self Reliant DC Microgrid: Sizing, Control, Adaptive Dynamic Power Management and Experimental Analysis. Journal of IEEE Transactions on Industrial Informatics, 14(8), 1-15. https://doi.org 10.1109/TII.2017.2780193

[13] Rishi, K. S. \& Sukumar, M. (2018). Dynamic Power Management and Control of PV PEM fuel Cell based Standalone AC/DC Microgrid Using Hybrid Energy Storage. IEEE Transactions on Industry Applications, 54(1), 526538. https://doi.org 10.1109/TIA.2017.2756032.

[14] Hamid, R. B., Graduate, M. M., Gevork, G. B., \& Heidar, A. T. (2017). Decentralized Sliding Mode Control of WG/PV/FC Microgrids Under Unbalanced and Nonlinear Load Conditions for On and Off Grid Modes. IEEE Systems Journal, 5(1), 1-12. https://doi.org10.1109/JSYST.2017.2761792

[15] Ming, Z., Junyi, Z., Gengyin, L., \& Jianwen, R. (2018). Distributed Dispatch Approach for Bulk AC/DC Hybrid
Systems With High Wind Power Penetration. IEEE Transactions on Power Systems, 33(3), 3325-3336. https://doi.org/10.1109/PESGM.2018.8585738

[16] Raymond, H. Byrne, N., David, A., Copp, B., Chalamala, R., \& Imre, G. (2018). Energy Management and Optimization Methods for Grid Energy Storage Systems. IEEE Access, 13231-13260. https://doi.org/10.1109/ACCESS.2017.2741578

[17] Zhe, Z., Wei, Q., \& Qing, H. (2019). Power System Stabilization Using Energy-Dissipating Hybrid Control. IEEE Transactions on Power Systems, 1(6), 215-224. https://doi.org/10.1109/TPWRS.2018.2866839

[18] Young, J. \& Dae, H. C. (2017). Distributed Optimization Framework for Energy Management of Multiple Smart Homes With Distributed Energy Resources. IEEE Access, (5), 2169-3536. https://doi.org/10.1109/ACCESS.2017.2734911

[19] Wenzhi, H., Feng, X., Fenglei, Z., Yongyan, Z., Kun, L., \& Yipan, T. (2019). Research on AC and DC hybrid power supply system with high proportion renewable energy of data centre. The Journal of Engineering, 16(3). 3230-3233. https://doi.org 10.1049/joe.2018.8925

[20] Md, S. A. \& Seyed, A. A. (2019). Energy Management in Power Distribution Systems: Review, Classification, Limitations and Challenges. IEEE Access, 99(1), 9297993001. https://doi.org/10.1109/ACCESS.2019.2927303

[21] Xinxi, T., Yan, X., Hongfei, W., \& Jian, Zhao. (2020). An Improved LLC Resonant Converter With Reconfigurable Hybrid Voltage Multiplier and PWM Plus PFM Hybrid Control for Wide Output Range Applications. IEEE Transactions on Power Electronics, 35(1), 185-197. https://doi.org/10.1109/TPEL.2019.2914945

[22] Hu, H., Fang, X., Zhang, Q. Z. J., Shen, Z. J., \& Batarseh, I. (2011). Optimal Design Considerations for a Modified LLC converter with wide input voltage range capability suitable for PV applications. IEEE Energy Conserver Congress, 3096-3103. https://doi.org 10.1109/APEC.2019.8721889

[23] Wu, H., Zhan, X., \& Xing, Y. (2017). Interleaved LLC Resonant Converter with Hybrid Rectifier and VariableFrequency Plus Phase-Shift Control for Wide Output Voltage Range Applications. IEEE Trans. Power Electron, 32(6), 4246-4257. https://doi.org/10.1109/TPEL.2016.2602545

[24] Wu, H., Li.Y. Y., \& Xing, Y. (2016). LLC Resonant Converter with Semi active Variable-Structure Rectifier (SA-VSR) for Wide Output Voltage Range Application. IEEE Trans Power Electron, 31(5), 3389- 3394. https://doi.org 10.1109/TPEL.2015.2499306

[25] Shang, M. \& Wang, H. Y. (2018). A Voltage Quadrupler Rectifier Based Pulse width Modulated LLC Converter with Wide Output Range. IEEE Trans. on Industry Applications, 54(6), 6159-6168. https://doi.org 10.1109/TIA.2018.2850033

[26] Subarni, P., Shadab, M., Bhim, S., \& Bijaya, K. P. (2019). Performance Investigation of Multifunctional On-Grid Hybrid Wind-PV System with OASC and MAF Based Control. IEEE Transactions on Power Electronics, 34(11), 10808-10822. https://doi.org/10.1109/TPEL.2019.2900759

[27] Bin, L., Weihan, W., Chunxiao, Z., Chengxiong, M., Dan, W., Qing, D., \& Guanglin, Sha. (2019). An AC-DC Hybrid Multi-Port Energy Router With Coordinated Control and Energy Management Strategies. IEEE Access, 7(1), 109069109082. https://doi.org 10.1109/ACCESS.2019.2933469

[28] Jun, C., Wenjuan, D., Haifeng, W., \& Malcolm, M. (2018). Optimal Sizing and Control Strategies for Hybrid Storage System as Limited by Grid Frequency Deviations. IEEE Transactions on Power Systems, 33(5), 5486-5495. https://doi.org/10.1109/TPWRS.2018.2805380

[29] Mohamed, S. T., Hussein, H. A., \& Yasser, A. R. M. I. (2015). An Online Energy Management System for a GridConnected Hybrid Energy Source. IEEE Journal of Emerging and Selected Topics in Power Electronics, 6(4), 2015-2030. https://doi.org/10.1109/JESTPE.2018.2828803 
[30] Nadjwa, C., Adel, M., Giorgio, S., \& Alessandro, M. P. (2018). Adaptive Neural Network Based Control of a Hybrid AC/DC Microgrid. IEEE Transactions on Smart Grid, 9(3), 1667-1679. https://doi.org 10.1109/TSG.2016.2597006

[31] Siddique, N. (2014). Intelligent Control: A Hybrid Approach Based on Fuzzy Logic, Neural Networks and Genetic Algorithms. Studies in Computational Intelligence, 517. https://doi.org 10.1007/978-3-319-02135-5

[32] Sulligoi, G., Bosich, D., Giadrossi, G, Zhu, L. M., Cupelli, M., \& Monti. A. (2014). Multiconverter Medium Voltage DC Power Systems on Ships: Constant-Power Loads Instability Solution Using Linearization via State Feedback Control. IEEE Trans. Smart Grid, 5(5), 2543-2552. https://doi.org 10.1109/TSG.2014.2305904

[33] Jose, G. de M., Luiz, A. de S. R., \& Evandro, de C. G. (2015). Power Control in AC Isolated Microgrids With Renewable Energy Sources and Energy Storage Systems. IEEE Trans. Indus. Electron, 62(6), 3490-3498. https://doi.org10.1109/IECON.2013.6699409

\section{Contact information:}

Karthik SURULI, Assistant Professor

(Corresponding author)

Department of Electrical and Electronic Engineering,

PSG College of Technology, Peelamedu,

Coimbatore-641 004, Tamilnadu, India

E-mail: karthiksuruli@gmail.com

Vennila ILA, Professor

Department of Electrical and Electronic Engineering,

PSG College of Technology, Peelamedu,

Coimbatore-641 004, Tamilnadu, India

E-mail: iven.eee@psgtech.ac.in 